\title{
Overconfidence and Investment Decisions in Nepalese Stock Market
}

\author{
Niyam Raj Shrestha'
}

\begin{abstract}
This paper assesses the effect of overconfidence bias of an individual on investment decisions. This study uses the descriptive statistics and follows analytical approach to analyse the effects of investors' behaviour on investment decisions. The data for the study were collected through questionnaire survey. This study finds that women investors, investors having college education, and investors having net worth between Rs 2 to 5 million are confident in their own ability. They believe that they are better investors than their peers and tend to trade more.
\end{abstract}

Key words: Behaviour Finance, Overconfidence, Behaviour Bias, Investment Decisions

\section{INTRODUCTION}

Behaviour finance is the body of research into the role that emotions and other subjective factors play in investment decisions (Gitman \& Joehnk, 2013). It is the study of how psychological phenomena can impact on financial behaviour (Shefrin, 2005). The behavioural perspective was initially presented as a challenge, or an alternative to traditional finance based in neoclassical economics, a process of adjustments into human's existing mass of theory (Forbes, 2009). The traditional finance model incorporates the presence of many buyers and sellers without abilities to influence the price of assets. In this assumption, investors form their expectations based on full use of available information. The expectations based models argue that the irrationality will be undone through the process of arbitrage (Friedman, 1953). The resulting biases will cause investors to overreact to certain types of financial information and underreact to other (Gitman \& Joehnk, 2013). Behavioural finance draws on the experimental evidence of

1. This paper was originally presented in the $10^{\text {th }}$ ORSN national conference on "Operation research and development" held on Feb 1-2, 2019 in Hetauda. It is the revised version of the paper and incorporates the valuable suggestions received from the conference participants. The author gratefully acknowledges the valuable suggestions received from the conference participants.

2. Mr. Shrestha is lecturer at Faculty of Management, Public Youth Campus,

Tribhuvan University. He can be reached at niyamshrestha@gmail.com 
the cognitive psychology and the biases that arise when people form beliefs, preferences and the way in which they make decisions, given their beliefs and preferences to explain investor irrationality and investors' decision-making process (Barberis \& Thaler, 2003).

Research in behavioural finance has developed rapidly in recent years. It provides evidence that investors' financial decisions are also affected by internal and external behavioural factors (Shleifer, 2000). Behavioural biases are generally classified as being of either a cognitive or emotional type. Some believe that a proper understanding of these biases and knowing the biases a person exhibits can allow these "irrationalities" to be predicted and modelled (Ariely, 2008). Cognitive biases and emotional biases are the most prominent biases of the behaviour finance. The availability, representativeness, confirmation bias, anchoring/conservation, overconfidence, illusion of money, house money effect, mental accounting and myopia are referred to cognitive biases. Similarly, emotional biases are loss aversion, fear of regret, optimism, aversion to ambiguity, endowment effect and snake bite effect. The researchers in behavioural finance believe that investors' decisions are affected by number of beliefs and preferences (Gitman \& Joehnk, 2013). Among all biases, the overconfidence bias also affect on investment decisions of investors.

Investors tend to be overconfident in their judgements, which frequently lead them to underestimate the level of risks in an investment (Gitman \& Joehnk, 2013). Overconfidence bias may affect experts and professionals more often than a novice investor. An overconfident investor may invest a greater portion of their portfolio in a single security. Overconfidence results in the investor not recognizing the possibility of being in error, and the risk of that error. Overconfidence may therefore result in a riskier portfolio than anticipated. In addition, overconfidence can cause financial analysts and money managers to make predictions that they are too bold and it may give false sense of security to the investors. Experts, investment bankers and manager have detected the overconfidence bias (Russo \& Schoemaker, 1992). Overconfidence is found to be toughest for questions of reasonable to thrilling difficulty (Griffin \& Tversky, 1992; Yates, 1990), and it seems to increase with the personal importance of the job (Frank, 1935). Adhikary (2010) reported that the respondent investors are mostly overconfident with regard to their self-reported level of investment-related knowledge, experience and their ability to pick stock. Dangol and Shrestha (2018) investigated the effect of personality traits on behaviour biases. These studies showed that all the investors analyse securities in the same way and share the same economic view of the world. Inventors use the same assumption that is referred to homogeneous expectation or beliefs. These beliefs are concerned with the investor's perception and their behaviour including overconfidence. This overconfidence bias affects investment decisions of the investors. Thus, this study focuses the issues - how does individual's overconfidence can influence in investment decisions among Nepalese investors? And how do selected variables like level of education, gender, etc., effect on overconfidence bias among Nepalese investor's in investment decision in Nepalese stock market? Therefore, the major objective of this paper is to analyse the influence of the individuals' overconfidence in investment decisionmaking. Further the study assesses the effect of educational qualification on individuals' 
overconfidence, and the link between gender and overconfidence among the individual investors in Nepalese stock market.

The remaining sections are divided into following order. Section II is the review of literature and develops conceptual framework. Section III describes the method and presents the research model. Section IV presents the results and finding, and section $\mathrm{V}$ discusses the major findings and draws conclusions.

\section{LITERATURE REVIEW AND CONCEPTUAL FRAMEWORK}

Kahneman and Tversky (1979) introduced prospect theory, which explained choice under uncertainty. Camerer and Lovallo (1999) found experimentally that overconfidence and optimism lead to excessive business entry. The behavioural finance literature shows that psychological biases, particularly in an uncertain and noisy environment, influence investors' information processing behaviour (Kahneman \& Riepe 1998, Barber \& Odean 2001). Barber and Odean (2001) argued that the illusion of control (e.g., people believe that they can influence the outcome of chance events), the illusion of knowledge (e.g., when people have far more data, they believe that they are more knowledgeable than they really are), and self-attribution bias (e.g., people tend to attribute their success to their own abilities while attribute their failure to bad luck) drive investors to be overconfident. Biais et al. (2005) studied the impact of judgmental overconfidence and self-mongering bias in the investment decision by observing the behaviour of 215 participants. The results showed that under calibration reduces and self-monitoring enhances trading performance.

Niederle and Vesterlund (2007) found that women were less willing to compete than men, even if their performance on a real experimental task is better as part to performance of men. Chen et al. (2007) studied the impact of disposition effect, representative bias, and experience and overconfidence bias on decision making of emerging market investor in China. Their result showed that the investors make a poor decision and biases had a significant effect on investors' decision. Kabra et al. (2010), Patidar (2010) concluded that investors' age and gender predominantly decides to the risk taking capacity of investors. Chandra and Kumar (2012) concluded that five major factors influence on individual investors' behaviour in Indian stock market, named as prudence and precautious attitude, conservatism, under confidence, informational asymmetry, and financial addiction. Bailey et al. (2011) studied the impact of behaviour biases on the mutual fund investments and found the mutual fund investors make a poor decision and they could not make a rational decision. Obamuyi (2013) found that characteristics of investors' age, gender, marital status and educational qualifications significantly influenced the investment decisions of investors in Nigeria. Gitman and Joehnk (2013) stated that the investors tend to be overconfident in their judgements, knowledge and skills. Sthapit (2017) showed the presence of a strong positive correlation of herding behaviour and overconfidence bias with investment decision making of individual investors in Nepalese secondary market. Likewise, the Nepalese investors' herding behaviour and overconfidence biases make strong impact on their investment decision making. Awale et al. (2018) found that majority of investors do not show overconfidence bias due to the fact that most of the investors 
that invest in secondary market of Nepal have no higher level education and do not know how to make proper investment analysis. Dangol and Shrestha (2018) examined the effect of personality traits on behaviour biases and found that there is significant positive relationship between extraversion trait and overconfidence bias stating that investors with higher positive emotions, excitements, full of energy tends to be overconfident than others.

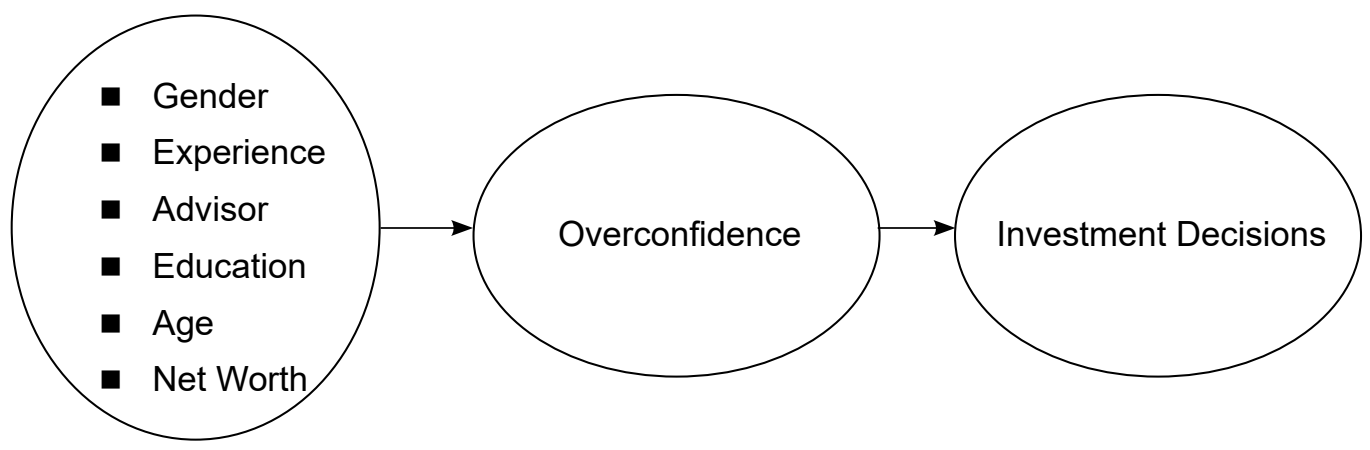

Figure 1. Study framework

The review of literatures reveals that the studies in different periods of time pointed out that the behavioural biases (overconfidence bias) of investors are essential to include in the investor's behaviour study. Such empirical evidences related to overconfidence bias are also important in context of small and underdeveloped capital markets like Nepal. The conceptual framework of this study is shown in figure 1.

\section{METHODS}

This study has used descriptive statistics and analytical approach to analyse the investors' behaviour on stock return. A questionnaire survey was conducted to collect investors' opinion and examine the overconfidence bias of the Nepalese investors. The respondents are the investors available at different broker's office in Kathmandu. Thus, convenient sampling method is applied to collect the data. Descriptive and analytical approach is used to interpret the patterns of relationships between the dependent variable and independent variables.

The questionnaires were distributed to the investors visiting at broker's office and they were the regular stock traders. Altogether 200 questionnaires were distributed to the respondents. Out of them 146 questionnaires were returned which represents average response rate of 73 per cent. The respondents were selected with the help of the broker's offices in Kathmandu.

The survey questionnaire consists of two sections. The first section is related to demographic information and second section is related to questions of overconfidence as used by Mooreland (2011). The second section of questionnaire attempts to find out the biases of overconfidence indicating that the investors tends towards overconfidence if the answers of the respondent's expected returns is 15 per cent or more. The study has employed probit individual equation regression model for the analysis. The positive 
effects of outcomes are expected in age, experience, advisor, education and net worth (Lin, 2011). The negative effect of outcome is expected in gender (Bashir et. al, 2013).

Overconfidence $=\beta_{0}+\beta_{1}($ Gender $)+\beta_{2}($ Experience $)+\beta_{3}($ Advisor $)+\beta_{4}($ Education $)+\beta_{5}($ Age 35$)$ $+\beta_{6}($ Age 45$)+\beta_{7}\left(\right.$ Age55) $+\beta_{8}($ NetWorth 250 $)+\beta_{9}($ NetWorth500 $)+\beta_{10}($ NetWorth 1000 $)+$ $\beta_{11}\left(\right.$ NetWorth1000) $+\varepsilon_{t}$

\section{RESULTS AND FINDINGS}

Respondent's profile and subject characteristics

A complete summary of the characteristics of the respondents in the sample, along with some basic findings are exhibited in table 1. In this survey as reported in table 1, a majority of respondents $(66 \%)$ are female and the rest $(34 \%)$ are male..

Table 1

Respondent's Profile and Subject Characteristics

\begin{tabular}{|c|c|c|}
\hline Characteristic & $\mathrm{N}$ & Per cent of total (\%) \\
\hline \multicolumn{3}{|l|}{ Gender: } \\
\hline Male & 50 & 34 \\
\hline Female & 96 & 66 \\
\hline \multicolumn{3}{|l|}{ Age: } \\
\hline Age 35 group (up to 35 years) & 40 & 28 \\
\hline Age 45 group (36-55 years) & 69 & 47 \\
\hline Age 55 group (56 years and above) & 37 & 25 \\
\hline \multicolumn{3}{|l|}{ Education (COL4): } \\
\hline High School & 35 & $24 \%$ \\
\hline Plus 2 or Intermediate & 7 & $5 \%$ \\
\hline Bachelor's Degree & 45 & $31 \%$ \\
\hline Masters' or Professional Degree & 9 & $6 \%$ \\
\hline $\begin{array}{l}\text { Vocational School other than college } \\
\text { Investment Yrs: }\end{array}$ & 50 & $34 \%$ \\
\hline None & 4 & 3 \\
\hline Less than 2 yrs & 12 & 8 \\
\hline $2-5$ years & 11 & 8 \\
\hline $6-10$ years & 26 & 17 \\
\hline More than 10 years & 93 & 64 \\
\hline \multicolumn{3}{|l|}{ Take Advise: } \\
\hline Use Advisor & 99 & 68 \\
\hline Do Not Use Advisor & 47 & 32 \\
\hline \multicolumn{3}{|l|}{ Net Worth: } \\
\hline Less than Rs. $0.5 \mathrm{~m}$ & 37 & 25 \\
\hline Rs. $0.5 \mathrm{~m}$ - Rs. $2 \mathrm{~m}$ & 35 & 24 \\
\hline Rs.2m - Rs.5m & 27 & 19 \\
\hline Rs. $5 m$ - Rs. $10 m$ & 28 & 19 \\
\hline Over Rs. 10 Million & 19 & 13 \\
\hline
\end{tabular}

Source. Survey, 2018 
32 I PYC Nepal Journal of Management, August 2019, Vol. XII, No. 1

Table 2

The regression result of overconfident bias

The dependent variable is questions on overconfidence and the independent variables are gender, investment experience, education, age and investment net worth. The F value of the model is $14.0(\mathrm{P}=0.000)$ and it is statically significant. The $\mathrm{R} 2$ of the model shows that it explains 18 per cent variations.

\begin{tabular}{|c|c|c|c|c|c|c|}
\hline \multirow{2}{*}{$\frac{\text { QOC }}{\text { Parameter }}$} & \multicolumn{3}{|c|}{ Individual Equations } & \multicolumn{3}{|c|}{ Multivariate Equations } \\
\hline & Estimate & Error & $\mathrm{P}>\mathrm{ChiSq}$ & Estimate & Error & $P>z$ \\
\hline Intercept & 0.0333 & 0.2448 & 0.8919 & 0.0300 & 0.2440 & 0.902 \\
\hline Male & $-0.3390^{*}$ & 0.1894 & 0.0732 & -0.3440 & 0.1891 & 0.069 \\
\hline Inv. Exp. & 0.0982 & 0.2453 & 0.6890 & 0.1182 & 0.2453 & 0.630 \\
\hline Advisor & -0.3760 & 0.1883 & 0.0459 & -0.3750 & 0.1888 & 0.047 \\
\hline Col4 & $-0.2140^{*}$ & 0.1785 & 0.2297 & -0.2160 & 0.1773 & 0.223 \\
\hline Age35 & 0.0457 & 0.2398 & 0.8490 & 0.0124 & 0.2412 & 0.959 \\
\hline Age45 & 0.3450 & 0.2439 & 0.1571 & 0.3567 & 0.2468 & 0.148 \\
\hline Age55 & $0.0350^{*}$ & 0.2246 & 0.8762 & 0.0111 & 0.2231 & 0.960 \\
\hline $\mathrm{Nw} 0.5 \mathrm{~m}$ & -0.0700 & 0.2255 & 0.7568 & -0.0570 & 0.2261 & 0.799 \\
\hline Nw2m & $0.1717^{*}$ & 0.2538 & 0.4989 & 0.1518 & 0.2527 & 0.548 \\
\hline Nw5m & 0.0244 & 0.2588 & 0.9248 & 0.0531 & 0.2592 & 0.838 \\
\hline $\mathrm{Nw} 10 \mathrm{~m}$ & -0.4530 & 0.2909 & 0.1193 & -0.4500 & 0.2908 & 0.122 \\
\hline
\end{tabular}

Source. Survey 2018, *Significant at 10\% level

Similarly, $47 \%$ respondents belong to Age 45 group (36-55 years), $28 \%$ belong to Age 35 group (up to 35 years), and the rest belong to Age 55 group. The education level of respondents shows that 26 per cent $(24 \%+5 \%)$ had school level education and $37 \%(31 \%+6 \%)$ had bachelors and masters' degree. The remaining $34 \%$ respondents had vocational degree other that the college degree. The investment experience of the respondents in survey shows that $16 \%(8 \%+8 \%)$ respondents had less than 5 years investment experience and $17 \%$ investors had 6 to 10 years investment experience. The majority respondents (64\%) had more than 10 years of investment experience. Only $3 \%$ respondents had no investment experience. On taking advice for investing, $68 \%$ respondents reported that they had taken the advice from the financial adviser and $32 \%$ did not take advice from the financial advisor and brokers for their investment decisions. Regarding the net worth of the investors, $67 \%(25 \%+24 \%+19 \%)$ respondents had net worth less than Rs. 5 million and $33 \%$ had more than 5 million. Fifty-two per cent survey respondents reported their annual income less than Rs. 750,000 and $48 \%$ reported annual income greater than that.

\section{Results from regression analysis}

The regression results presented in table 2 enables to analyse what type of participants are likely to exhibit a certain behaviour or bias. They are further used to determine whether the participants are overconfident or not. The negative coefficient for males indicates that females tended to show more overconfidence than males. This result is similar to the finding of the Kalambokidis (2011) and Lewellen et al. (1977). 
When participants are asked how the performance of their portfolios would compare to other investors; COL4 (highly educated investors) have very significant and positive coefficients. It shows that they are quite confident in their ability. The result on the variable advisor is insignificant, therefore, advises from financial experts do not lead investors to overconfidence. .The education variable (COL4) is significant; it indicates that the respondents are overconfident if they have higher education. Similarly, in age variable, the coefficient of Age 35 and Age 45 groups are not significant while it is significant for Age 55 group. It shows that elder respondents are overconfident than younger investors. This result is similar to the finding of Lin (2011).

On net worth, the respondents with net worth of $0.5 \mathrm{~m}(\mathrm{Nw} 0.5 \mathrm{~m})$ and net worth 10 $\mathrm{m}(\mathrm{Nw} 10 \mathrm{~m})$ have small and insignificant coefficients. But, the coefficient for net worth of $2 \mathrm{~m}(\mathrm{Nw} 2 \mathrm{~m})$ is significant, it shows that the investors in this net worth group are more overconfident than other net worth groups.

\section{DISCUSSION AND CONCLUSIONS}

This study has provided evidence that investors have overconfident biases due to positive coefficient in the model tested. This result is similar to the finding of the Kalambokidis (2011). This overconfidence bias influences the decisions with respect to investor's investments. Overconfident investors believe that they are better investors than both their peers and a stock market index. With respect to overconfidence, women in the study are too confident in their own ability than male respondents. This finding is comparable with previous research works including Lewellen et al. (1977), Barber and Odean (2001) and Niederle and Vesterlund (2007). Managing investors' overconfidence bias helps in optimizing the investment returns from the Nepalese stock market. This indicates that the overconfident investors' investment decisions that have superior information that tend to trade more, but earn lower return due to the higher transaction costs. Similarly, during a period of economic expansion and stock market gains, the overconfident investor will shift to a portfolio that requires more risk than s/he is comfortable with as s/he looks for greater returns, and the success of selecting "winning" stocks would further fuel the investor's overconfidence. In a period of stock market losses, the overconfident investor would hold losing investments and may even add to the losing positions, because s/ he believes the stock price is lower due to the ignorance of other investors, rather than accept the fact that he made a bad investment decision.

\section{REFERENCE}

Adhikary, P. (2010). Investment behaviour of Nepalese investors. PYC Nepal Journal of Management, 3(1). 47-58. Retrieved from: http://www.pyc.edu.np/index.php?option=com_co ntent\&view=article\&id=423:investment-behaviour-of-nepalese-investors- $\&$ catid=85:volumeiii-2010\&Itemid=447

Ariely, D. (2008). Predictably irrational: The hidden forces that shape our decisions. New York: Harper Collins Publishers. 
34 I PYC Nepal Journal of Management, August 2019, Vol. XII, No. 1

Awale, S. L., Pandey, D. R., Sapkota, D. R. \& Shrestha, K. C. (2018). A study of disposition effect, overconfidence bias and herding behaviour in Nepalese investors (An unpublished MBA project research report, Kathmandu University).

Bailey, W., Kumar, A., \& Ng, D. (2011). Behavioural biases of mutual fund investors. Journal of Financial Economics, 102(1), 1-27. Retrieved from: https://courses.cit.cornell.edu/wbb1/ papers/Bailey_Kumar_Ng_FOR_JFE_16July2010.pdf

Barber, B. M., \& Odean, T. (2001). Boys will be boys: Gender, overconfidence, and common stock investment. The Quarterly Journal of Economics, 116(1), 261-292. Retrieved from: https:// academic.oup.com/qje/article-abstract/116/1/261/1939000?redirectedFrom=fulltext

Bashir et al. (2013). Are Behavioral Biases Influenced By Demographic Characteristics \& Personality Traits? Evidence from Pakistan. European Scientific Journal, 9(29), 277-29. Retrieved from: https://eujournal.org/index.php/esj/article/view/1928/1870

Barberis, N. \& Thaler, R. (2003). A survey of behavioural finance. Handbook of the Economics of Finance, 1(2), 1051-1121. DOI: https://doi.org/10.1016/S1574-0102(03)01027-6

Biais, B., Hilton, D., Mazurier, K. \& Pouget, S. (2005). Judgemental overconfidence, selfmonitoring and trading performance in an experimental financial market. Review of economic studies, 72(2), 287-312. Retrieved from: https://www.jstor.org/stable/3700653?seq=1

Camerer, C., \& Lovallo, D. (1999). Overconfidence and excess entry: An experimental approach. The American Economic Review, 89(1), 306-318. DOI: 10.1257/aer.89.1.306

Chandra, A. \& Kumar, R. (2012). Factors influencing Indian individual investor behaviour, Survey Evidence Decision, 39(3), 141-167. Retrieved from: https://ssrn.com/abstract=2029642 or http://dx.doi.org/10.2139/ssrn.2029642

Chen, G. M., Kim, K., Nofsinger, J. R., \& Rui, O. M. (2007). Trading performance, disposition effect, overconfidence, representativeness bias, and experience of emerging market investors. Journal of behavioral decision making , 20(4), 425-451. DOI: 10.1002/bdm.561

Dangol, J. \& Shrestha, A. (2018). Influence of demographics and personality traits on the behaviour biases. Kathmandu: New Hira Books Enterprises.

Forbes, W. (2009). Behavioural finance. New Delhi: Jonh Willy \& Sons, Inc.

Frank, J. D. (1935). Some psychological determinants of the level of aspiration, American Journal of Psychology, 47(1), 285-293. Retrieved from: https://www.jstor.org/stable/1415832?seq=1

Gitman, L. J. \& Joehnk, M. D. (2013). Fundamentals of Investing. New Delhi: Dorling Kindersley (India) Pvt. Ltd.

Griffin, D. \& Tversky, A. (1992). The weighing of evidence and the determinants of confidence, Cognitive Psychology 24(1), 411-435.

Kabra G., Mishra, P. K., \& Dash, M. K. (2010). Factors influencing investment decision of generations in India: An econometric study. Asian journal of management research, 4(9), 308-325. Retrieved from: http://citeseerx.ist.psu.edu/viewdoc/download;jsessionid=12880CE DE9F87F3EE3738DC28549D6BB?doi=10.1.1.207.2671\&rep=rep1\&type=pdf

Kahneman, D. \& Riepe, M. W. (1998). Aspects of investor psychology. Journal of Portfolio Management, 24(4), 52-65. Retrieved from: https://www.turtletrader.com/investorpsychology.pdf

Kahneman, D. \& Tversky, K. (1979). Prospect theory: An analysis of decision under risk. Econometrica, 47(2), 263-292. Retrieved from: https://www.uzh.ch/cmsssl/suz/dam/ jcr:00000000-64a0-5b1c-0000-00003b7ec704/10.05-kahneman-tversky-79.pdf

Kalambokidis, L. (2011). Irrational investor's risk profile. Minnesota: The University of Minnesota. 
Lewellen, W. G., Ronald, C. L. \& Gary, G. S. (1977). Patterns of investment strategy and behavior among individual investors. Jounral of Business, 50(3), 296-333. Retrieved from: https:// www.jstor.org/stable/2352539?seq=1

Lin, H. W. (2011). Elucidating the influence of demographics and psychological traits on investment biases. International Journal of Social, Behavioral, Educational, Economic, Business and Industrial Engineering, 5(5), 424-429. Retrieved from: https://pdfs. semanticscholar.org/2375/2c0aeeef39c20034607f3fb08f738f389795.pdf

Moorland, J. J. (2011). The irrational investor's risk profile. Minnesota: University of Minnesota (An unpublished master's thesis submitted to University of Minnesota, USA).

Niederle, M. \& Vesterlund, L. (2007). Do women shy away from competition? Do men compete too much? Quarterly Journal of Economics, 122(3), 1067-1101. DOI: https://academic.oup. com/qje/article-abstract/122/3/1067/1879500

Obamuyi, T. M. (2013). Factors influencing investment decisions in capital market: A study of individual investors in Nigeria. Organizations and Markets in Emerging Economies, 4(1), 141-161. Retrieved from: https://www.researchgate.net/publication/336246434_Factors Influencing_Investment_Decisions_in_Capital_Market_a_Study_of_Individual_Investors_in_ Nigeria

Patidar, S. (2010). Investors' behavior towards share market. International research journal, 1(13), 55-57.

Russo, J. E. \& Schoemaker, P. J. H. (1992). Managing overconfidence, MIT Sloan Management Review 33(1), 7-17. Retrieved from: https://sloanreview.mit.edu/article/managingoverconfidence/

Shefrin, H. (2005). A Behavioral approach to asset pricing. Boston: Elsevier Academic Press.

Shleifer, A. (2000). Inefficient markets: A introduction to behavioural finance. Oxford: Oxford University Press.

Sthapit, A. (2017). Impact of behavioural factors on share investment decisions: A study of herding behaviour and overconfidence biases of Nepalese investors. This paper was presented in $7^{\text {th }}$ international conference on "Global peace through emotional literacy in education and psychology of management" in Prime College Kathmandu jointly organized by World Without Anger \& Global Peace Foundation Nepal. Retrieved from: http:// wwaintljournal.org/images/abstract/abstract-7.pdf

Yates, J. F. (1990). Judgment and decision making. New Jersey: Prentice-Hall Inc.

Annexure

Survey Questionnaire

OVERCONFIDENCE AND INVESTMENT DECISION IN NEPALESE STOCK MARKET

Dear Sir/Madam,

I would like to request you to fill this questionnaire on the base of your experience in investment in Nepal Stock Exchange. The information obtained in this survey will be kept confidential and will be used for the sole purpose of this research. Please tick $[\sqrt{ }]$ in appropriate answer.

1. Your gender
a) Male [ ]

Niyam Raj Shrestha. Lecturer, Public Youth Campus

2. Your age group

a) Age 35 group (Up to 35 years) [ ] $\quad$ b) Age 45 group (36 to 55 years) [ ]

c) Age 55 group (above 55 years) [ ] 
3. Your experience of investment in stock market.
a) None [ ] b) Less than two years [ ]
c) Between 2 - 5 years [ ]d) Between 6 - 10 years [ ]
e) More than 10 years [ ]
4. Do you use a financial advisor/planner for any part of your investment portfolio?
a) Yes, I use an advisor/planner [ ] b) No, I do not use an advisor/planner [ ]

5. Your highest level of education.
a) High School [ ]
b) + 2 Degree or Intermediate [ ]
c) Bachelor's degree [ ]
d) Master's Degree [ ]
e) Vocational School other than College [ ]

6. Please specify your net worth of your investment portfolio.
a) Less than Rs. 5,00,000 [ ]
b) Rs. $5,00,000$ - Rs. $20,00,000$ [ ]
c) Rs. $20,00,000$ - Rs.50,00,000
d) Rs. 50,00,000 - Rs. 1 Crore [ ]
e) Over Rs. 1 Crore [ ]

7. Fund $X Y Z$ invests in stocks and has an annualized (yearly) return of $18 \%$ per year over the past 10 years. The fund remained invested in stocks during good and bad times.

Investors in the fund can choose to invest or not invest in the fund at various times based upon the economic conditions and expected return.

Given the flexibility investors have, how do you think the average investor in Fund ABC performed?
a) Between $15 \%$ and $30 \%$ [ ]
b) Between $0 \%$ and $15 \%$ [ ]
c) Better than $30 \%$ [ ]
d) Worse than $-1 \%$ [ ]

Note: Expected returns of $15 \%+$ indicates overconfidence

8. A recent publication advertised the great advancements of drugs to treat cancer and is almost certain to receive govt. approval this year. Biotechnology companies that make these drugs would benefit substantially from govt. approval.

After much research, you believe biotech stocks could double in value over the next year.

You currently have a $5 \%$ exposure to biotech stocks in your account. But you realize that if you put half of your investments in biotech and it doubles (as you believe) that you will reach your retirement goal 5 years ahead of schedule.

What would you do?

$\begin{array}{ll}\text { a) Increase biotech to } 50 \% \text { of portfolio. Chance to retire } 5 \text { years early! } & \text { [ ] } \\ \text { b) Increase biotech to } 25 \% \text { of portfolio. Chance to retire } 2.5 \text { years early! [ ] } \\ \text { c) Keep allocation the same. Not going to retire earlier than planned. }\end{array}$ Note: Increasing allocation to either $25 \%$ or $50 \%$ demonstrates overconfidence 